\title{
CHANGING MEDITERRANEAN ENVIRONMENT: IRREFUTABLE EVIDENCE FROM PRE-INDUSTRIAL, UNPUBLICISED SCENES CONTEMPORARY WITH A MISSION (1786-1787) IN THE LEVANT
}

\section{S. RHIZOPOULOU}

Received: 20/03/11

Accepted: 02/02/12

\author{
Department of Botany, Faculty of Biology, \\ National and Kapodistrian University of Athens, \\ Athens 15784, Greece
}

\section{ABSTRACT}

This paper provides an introduction to one hundred thirty one, pre-industrial, unpublicised Mediterranean scenes kept in Oxford, which constitute valuable evidence of changing environment. The largely unknown and unpublished paintings witness environmental wilderness and the cultural landscapes of the region, late in the 18th century. They depict sixty two scenes from Greece, forty two from Turkey, twenty two from Italy, three from Cyprus and two from Gibraltar. The paintings reveal changes that have occurred over the last two centuries in Mediterranean ecosystems; uninhabited areas, mountainous expanses, coastal regions, and Aegean islands. The region belongs to the hotspots of the biodiversity on Earth. Scientific interest in archival material has been revived, on account of research into a diversity threatened by anthropogenic activities and climate change. In this context, unknown Mediterranean scenes of 18th century offer another perspective on this complex subject of enquiry, they support efforts towards protection and preservation of natural environment and heighten interest in the management of diverse Mediterranean ecosystems.

KEYWORDS: Aegean - Greece - Cyprus - nature - Italy - Oxford - Turkey - wilderness.

\section{INTRODUCTION}

It was during the first journey of Professor John Sibthorp (1758-1796) from Oxford to Greece (1786$1787)$ that the Austrian painter Ferdinand Bauer (1760-1826) drew numerous Mediterranean scenes. Bauer studied landscape painting in the celebrated studio of Brand in Vienna and he assisted in the library and the botanical garden of Vienna (Lhotskt, 1843). It was in this context that he was introduced to J. Sibthorp, Professor of Botany at the University of Oxford (Bruce, 1970), who visited Vienna in order to see two famous manuscripts of Dioscorides, in the course of his preparations for a scientific exploration in the South Eastern Mediterranean (Harris, 2007). Sibthorp's main interest was the wealth of plants known since the classical antiquity in unexplored areas of Greece and he hired Ferdinand Bauer as the draughtsman of his mission in Eastern Mediterranean (Stearn, 1976; Lack and Mabberley, 1999; Krimbas, 2004; Rhizopoulou, 2004; Harris, 2007). This was a time when travellers were accompanied by a professional artist, whose work supplemented their discoveries with visual evidence (Nickelsen, 2006). Over the course of their journey from 1786 to 1787, a large number of plant-, animal- and geological-specimens were collected. Ferdinand Bauer made on-site sketches as preparation for his extraordinary detailed and accurate watercolours, illustrating living organisms and landscapes (Wise, 1989; Lack and Mabberley, 1999; Harris, 2007). Although, the monumental edition Flora Graeca (Sibthorp and Smith, 1806-1840) illustrated by Ferdinand Bauer, is considered the most splendid and expensive Flora ever produced, his work with Mediterranean landscape paintings has not been publicized and is still unknown. Environmental scenes support efforts towards the protection, the culture and preservation of natural environment (Smocovitis, 2003; Kent, 2009). Also, pictorial representations of landscapes reveal interactions among factors affecting the size of the regional species pool and 
of locality acting processes such as competition, disturbance, productivity and seasonality (Kay et al., 1997; McAllister et al., 2009).

The purpose of his work was to present Mediterranean scenes contemporary with a scientific exploration in the region and simultaneous, irrefutable evidence of environmental status. With skill and sensitivity F. Bauer conveyed information about South Eastern Mediterranean region. His Mediterranean scenes in conjunction with Flora Graeca Sibthorpiana (Sibthorp and Smith, 18061840), herbarium specimens (Lack, 1997) and the unpublished Fauna Graeca Sibthorpiana (Sclater, 1904), all housed in Oxford University, disclose wide aspects of Mediterranean ecosystems.

\section{MATERIALS}

The original, folio, monochrome landscape paintings $(48.7 \mathrm{~cm} \times 29.5 \mathrm{~cm})$ from Eastern Mediterranean by Ferdinand Bauer were observed at the Department of Plant Sciences of Oxford University (MS Sherard 408) during scientific visits in 2006 and 2009, in the context of a broader research project on Flora Graeca of Sibthorp (Rhizopoulou, 2004; Harris, 2007; Rhizopoulou, 2007; Rhizopoulou and Harris, 2009). The whole collection of the extremely rare edition Flora Graeca, which is kept at the Department of Plant Sciences at the University of Oxford, is not accessible to the public. Also, it seems likely that Mediterranean scenes by Bauer were not made at Sibthorp's request and they were not included in the material related to the Flora Graeca and deposited at the University of Oxford after Sibthorp's death in 1796; they were devolved to the University of Oxford in 1932, i.e. 136 years after Sibthorp's death (Harris, 2007). Subsequently, the program "Flora Graeca in the twenty-first century" brought to light one hundred thirty one Mediterranean scenes by Ferdinand Bauer (Appendix 1), which are now accessible via the web (Digital Flora Graeca) and can be studied from distance.

\section{RESULTS AND DISCUSSION}

The Mediterranean scenes by F. Bauer depict sixty two scenes from Greece, forty two from Turkey, twenty two from Italy, three from Cyprus and two from Gibraltar (Figs 1,2). The drawings are contemporary with the mission (1786-1787) in the Levant, since Bauer numbered them according to the order of places they were visited (Appendix 1, Fig. 2).

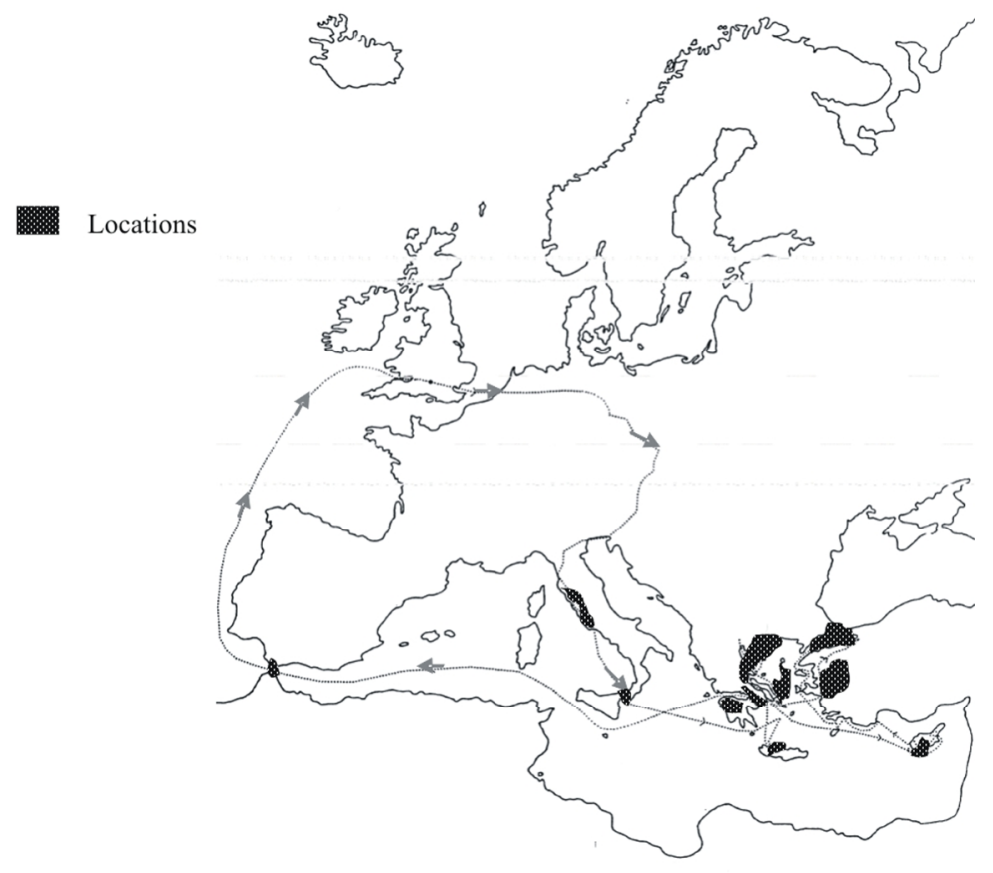

Figure 1. Sites of Mediterranean scenes by Ferdinand Bauer (darkened hatched areas), during the first journey of J. Sibthorp and F. Bauer (1786-1787) indicated by line and arrows 


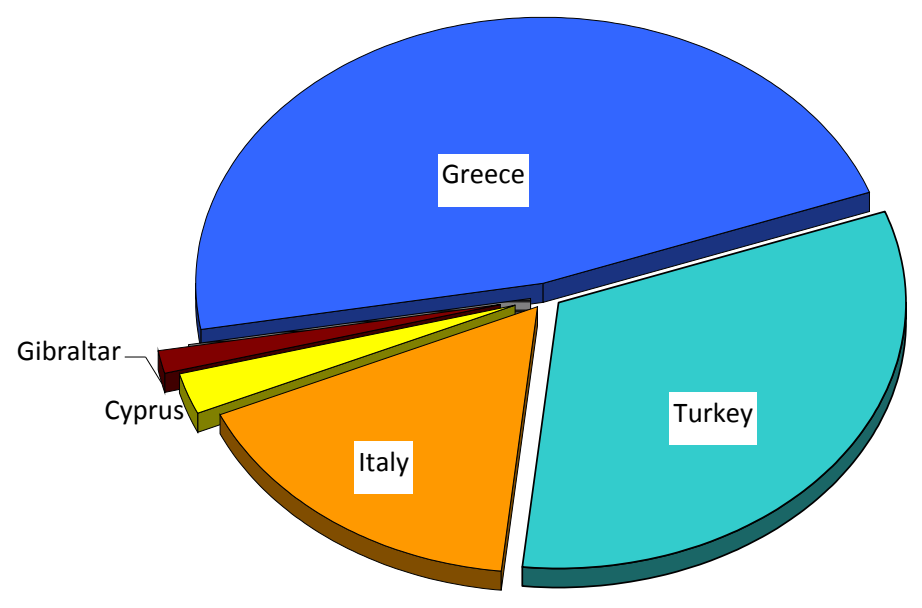

Figure 2. Geographical status of pre-industrial Mediterranean scenes by F. Bauer

The first twenty-two landscapes depict scenes from Italy, i.e. volcanic areas, views of Rome, Naples and Sicily, during spring of 1786 . The following scenes portray islands of Greece, i.e. Kythera, Milos and Crete. In the Cretan interior, a monastery with clusters of cypresses and treacherous mountainous regions, indicate locations where they pursued native and medicinal plants. After departing from Crete and heading towards Athens, Bauer captured the aridity of various islands in Aegean archipelagos. The travellers set sail for the coasts of Turkey and travelled thence following in caravan the traditional routes into the interior, via mountainous areas illustrated in three landscapes. The delightful environment of Istanbul was the subject of twenty paintings; a cemetery, the Besiktas Shore Palace and an ancient aqueduct diverge from the usual focus on the natural environment. These were followed by views of the Black Sea, a village near Istanbul, the Princes islands and the Sea of Marmara; in particular, the depictions of views with ancient fortifications preserved the historical memory of the place. Bauer displayed considerable interest in the pictorial cartographic landscapes of European and Asian coasts in this strategic region and he developed some panoramic views in either two or four illustrations on a single plate. In several scenes ports, defensive structures near tidal waters and ancient monuments dominate (Fig. 3). Few of the Mediterranean scenes convey the spirit of locations and the genius loci of cities, such as Athens, Istanbul and Rome, which may carry their identity into the future to the extent that they face their past.

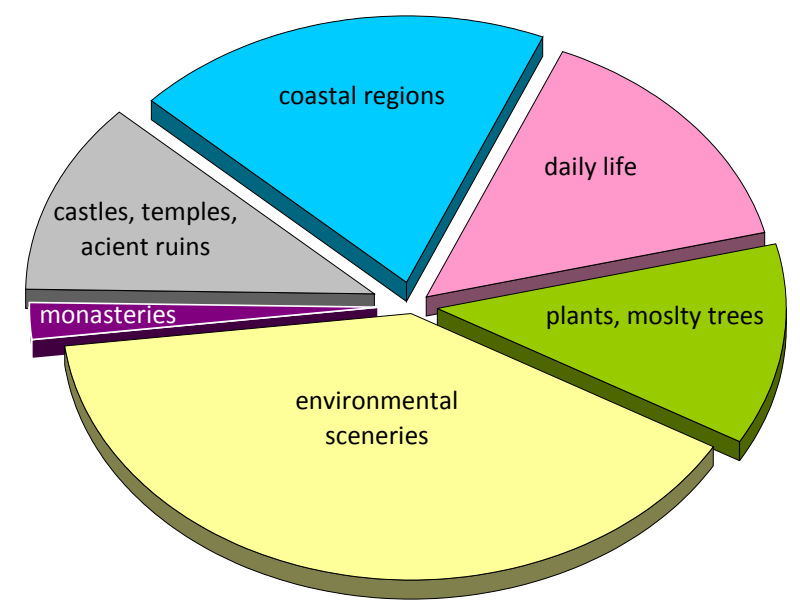

Figure 3. Status of scenic character of Mediterranean scenes by F. Bauer

In considering the natural environment, the journey through Cyprus was one of the most successful parts of the exploration to the Eastern Mediterranean; they collected hundreds of specimens. It is noteworthy that Sibthorp's group was the first scientific mission of naturalists to reach Cyprus, as 
the famous explorer of the eastern Mediterranean J. Pitton de Tournefort (1656-1708) did not visit this island. Also, the mission was the first to reach Mt. Parnassus, in the mainland of Greece, in recent times and the second to the mountainous environment and monasteries of the Athos peninsula in the north of Greece. In the Levant, ancient knowledge of healing properties of natural products from living tissues was well preserved in monasteries; their gardens and cultivated fields were a natural focus of interest for scientific inquiry (Lardos, 2006; Rhizopoulou, 2008). As the summer of 1787, with its few flowering plants, drew to an end, so did the mission to the Eastern Mediterranean. Sibthorp and Bauer returned to England by sea in the winter of 1787.

Sibthorp's idea to execute a naturalist exploration of the eastern Mediterranean was realized through hard work, under field conditions, late in the 18th century. It was an outstanding achievement, especially in light of the short time in which the samples from living organisms were collected and the wide-ranging geographical coverage of the expedition (Fig. 1). Only after Flora Graeca was eventually published (1806-1840) and the main participants in the expedition were no longer alive, the interest in the eastern Mediterranean began to increase in the 19th century. The region was incorporated into the Grand Tour tradition as a major source of knowledge. The curiosity of travellers was nourished by knowledge of natural history and archaeology; some of them even earned themselves the appellation "Levant lunatics" (Tregaskis, 1979). Descriptions of naturalists in the 18th and 19th century played an important role in the more general development of ecological thought (Mayr, 1982). Also, a sizeable reading public was (and still is) interested in travellers' chronicles, graphic images and pictorial landscapes that revealed the natural history and physiography of this region.

Recently, interest in Flora Graeca has been revived (Strid and Strid, 2009) on account of research into a biodiversity threatened by climate change. The region has been identified as belonging to one of the world's biodiversity hotspots (Myers et al., 2000) and it is characterized by endemism richness (Naveh, 1998; Başkale and Kaya, 2009; Georghiou and Delipetrou, 2010; Lymberakis and Poulakakis 2010; Pafilis, 2010; Türe and Böcük, 2010). Numerous places viewed in the 18thcentury Bauer's paintings were designated as "Natura" sites under the EC directives, at the beginning of the 21st century and heighten the interest in the study of the diversity of ecosystems. However, Eastern Mediterranean ecosystems have been profoundly influenced by human impact and issues of environmental concern have become very important; for example, land cover changes and land degradation has attracted attention (Jones-Walters and Čivić, 2010). In this aspect, landscapes paintings are "visual symbols" of a particular time, indicating considerable changes occurring in the regional environment throughout two centuries (Antrop, 2005; Daskalothanassis, 2004; Vogiatzakis et al., 2006).

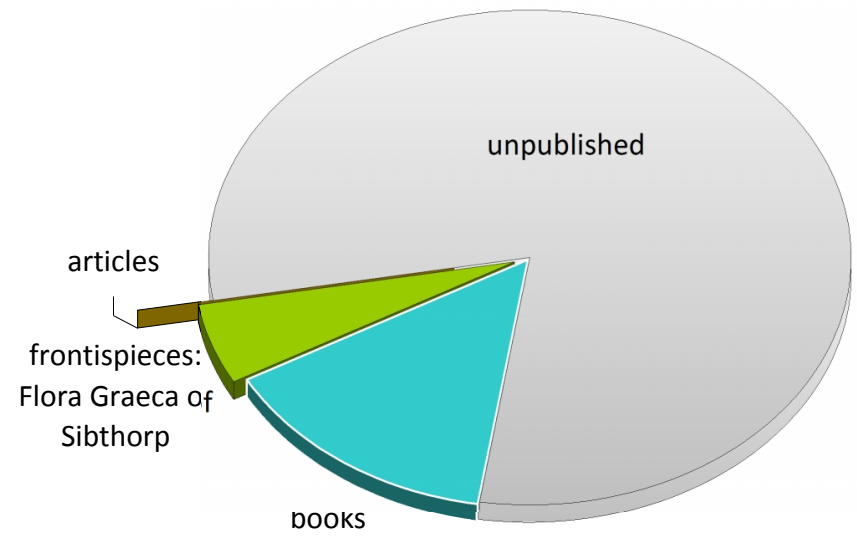

Figure 4. Publicised status of Mediterranean scenes by F. Bauer

Mediterranean scenes by Ferdinand Bauer were completed in England before 1794 and remained unpublished from that time until the 21 st century. There are very few references to this work in the international literature, while twenty four Mediterranean scenes were publicized (Appendix 1) with the circulation of books and articles (Harris, 2007; Lack and Mabberley, 1999; Mills and Townsend, 1991; Rhizopoulou, 2004; Wise, 1989). Seven hand-coloured engravings of Bauer's landscapes appear in vignettes on frontispieces of seven volumes of Flora Graeca (Fig. 4, Appendix 1) and 
reached a limited audience of this highly exclusive edition. According to the best of our knowledge, except all the aforementioned publicized drawings, one hundred seven Mediterranean scenes by Bauer still remain unknown and unpublished (Fig. 4).

The term "landscape" emerged as a way of seeing the external world. It was, and it remains, a visual term, closely bound up with wilderness, space and roughness of the environment, where balance and harmony are believed to depend on absence of permanent habitation. The term "landscape" is frequently used in natural conservation, management, ecology, geography and archaeology, linking all these diverse spaces with the idea that their qualities as dwelling habitats are rendered visible in pictorial form (Cosgrove, 2006).

Ferdinand Bauer conveyed information about South Eastern Mediterranean landscapes: uninhabited countryside, rocky mountainous expanses, seaside scenes, bays, inlets, harbours, villages, ancient monuments, monasteries, temples and castles with historical and strategic importance. Monuments did exist indeed; as splendid evidence of past glories the remains they come across in their journey. All were rendered by the artist's hand in pencil and pen with black ink, sometimes diluted to achieve shades of grey. He pictured the two gateways of the Mediterranean Sea: Dardanelle at the eastern end and Gibraltar at the west (at a time before the Suez Canal). Islands with cliffs, beaches, distant hills and steep slopes characterize a plethora of habitats of adapted organisms. In many of these scenes, we behold from a distance landscapes which would appear uninhabited and hostile to plant life (Braudel et al., 1985; Baltas et al. 2010). Gradually, living organisms adjusted to the harsh environment of brackish soils, caves and arid islands become objects of study, while terms such as ecological biogeography and geographical ecology mutated into environmental physiology (Mayr, 1982). Bauer depicted scenes of daily life, illustrating linkages between biotic and inorganic factors in the region (McAllister et al., 2009).

Bauer's landscape paintings constitute precious and highly valuable evidence for changes in both environmental forms and cultural landscapes, as well as for some vanished landscapes. For example, several places illustrated in his paintings have retained, to the present, a role as tourist centres (Harvey, 2001; Vogiatzakis et al., 2006). Pictorial landscapes are also for interest, for that they show -rarely depicted before- landscapes earlier than those recorded by travellers in the early 19th century (Harris, 2007). They support efforts towards the protection and preservation of both the natural environment and the cultural heritage (Terkenli, 2001).

When Bauer was in England (1787-1793) producing his artistic renderings of illustrations related to biodiversity, natural history and physiography of South Eastern Mediterranean, other travellers were publishing their works with descriptive views and drawing comparisons between the past and the present of this region. Amidst this exchange of information and flurry of publication from the 18th to the 20th century, the work of Ferdinand Bauer on Mediterranean scenes was not publicized; as far as we know, it was neither his responsibility, nor his obligation.

The unpublished, Mediterranean scenes can be viewed two centuries after their creation in detail via the web (Digital Flora Graeca). Picturesque landscape images visible in historical depth are consistently threatened by, if not already lost to, the past (Cosgrove, 2006). Bauer's drawings represent a unique heritage for scenic characteristics of the environment in South Eastern Mediterranean, revealing the many changes they underwent in the environment and enable us to predict future changes and transformation more reliably. Also, the scientific significance of the images today can be expanded to the analysis of the biodiversity. Further investigation will be required to test this hypothesis.

\section{CONCLUSION}

The largely unknown, pre-industrial landscape paintings witness wildernesses and changing environment in the South Eastern Mediterranean region. The landscape paintings by $\mathrm{F}$. Bauer, which are kept in Oxford, depict regional scenic traits and constitute valuable evidence for vanished landscapes. Revived interest in archives reflects interest in environmental management of the region.

\section{ACKNOWLEDGEMENTS}

Thanks are due to Dr. Stephen Harris for hospitality and access to archives of the University of Oxford, and to the British Council for financial support. 


\section{APPENDIX 1}

Mediterranean Scenes by Ferdinand Bauer; first column: numbering of scenes and second column scenes labelled by the artist in a continuous sequence according to the order of places visited by the mission (1786-1787). Landscape paintings' numerical disorder is indicated by asterisk $\left(^{*}\right)$

\begin{tabular}{|c|c|c|c|}
\hline Number & Scene and legend & Country & Reference \\
\hline 1 & 1: Colosseum at Rome & Italy & Lack and Mabberley, 1999 \\
\hline 2 & 2: the bay of Naples & Italy & - \\
\hline 3 & 3: Vesuvius & Italy & Harris, 2007 \\
\hline 4 & 4: Vesuvius & Italy & Lack and Mabberley, 1999 \\
\hline 5 & 5: Vesuvius & Italy & - \\
\hline 6 & 6: a grotto Paysilipon & Italy & - \\
\hline 7 & 7: Solfa Terra & Italy & - \\
\hline 8 & 8: ruins & Italy & - \\
\hline 9 & 9: a temple & Italy & - \\
\hline 10 & 10: Flegrean islands & Italy & - \\
\hline 11 & 11: a coast of Naples & Italy & - \\
\hline 12 & 12: Capri & Italy & - \\
\hline 13 & 13: Capri & Italy & - \\
\hline 14 & 14: a fisherman's house, Capri & Italy & - \\
\hline 15 & 15: Capri & Italy & - \\
\hline 16 & 16: a castle in Capri & Italy & - \\
\hline 17 & 17: ruins in Capri & Italy & - \\
\hline 18 & 18: remains of a bath building & Italy & - \\
\hline 19 & 19: Panara, Stromboli & Italy & - \\
\hline 20 & 20: Vulcana, Lipari, Saline & Italy & - \\
\hline 21 & 21: Aetna & Italy & Harris, 2007 \\
\hline 22 & 22: Messina & Italy & - \\
\hline 23 & 23: Kythera & Greece & - \\
\hline 24 & 24: small islands and Milos & Greece & - \\
\hline 25 & 25: rocks near Milos & Greece & Lack and Mabberley, 1999 \\
\hline 26 & 26: harbour in Milos & Greece & - \\
\hline 27 & 27: Chania in Crete & Greece & Lack and Mabberley, 1999 \\
\hline 28 & 28: Holy Trinity monastery & Greece & Harris, 2007 \\
\hline 29 & 29: Sphakia in Crete & Greece & - \\
\hline 30 & 30: Sphakia in Crete & Greece & - \\
\hline 31 & 31: Hydra island & Greece & - \\
\hline 32 & 32A: Egina island & Greece & - \\
\hline 33 & 32B: Siphnos island & Greece & - \\
\hline 34 & 33: the grotto of Antiparos & Greece & - \\
\hline 35 & 34: the grotto of Antiparos & Greece & Lack and Mabberley, 1999 \\
\hline 36 & 35: the grotto of Antiparos & Greece & - \\
\hline 37 & 36: Amorgos island & Greece & - \\
\hline 38 & 37: Amorgos island & Greece & - \\
\hline 39 & 38: remains of a temple in Samos & Greece & - \\
\hline 40 & 39: Dilek Daği & Turkey & - \\
\hline 41 & 40: Kousandasi & Turkey & - \\
\hline 42 & 41: a caravan & Turkey & Lack and Mabberley, 1999 \\
\hline 43 & 42: Mt Olympus of Bithynia & Turkey & Harris, 2007 \\
\hline 44 & 43: Mt Olympus of Bithynia & Turkey & vignette, 3rd frontispiece Flora Graeca \\
\hline 45 & 44: Mt. Olympus with Bursa & Turkey & Lack and Mabberley, 1999 \\
\hline 46 & 45S: the Seraglio point & Turkey & Lack and Mabberley, 1999 \\
\hline 47 & 46S: Istanbul & Turkey & - \\
\hline 48 & 47S: Istanbul & Turkey & - \\
\hline 49 & 48: View from Asia to Bosporus & Turkey & - \\
\hline 50 & 49S: Bosporus & Turkey & - \\
\hline 51 & 50: Channel of Istanbul & Turkey & - \\
\hline 52 & 51S: Büyükdere & Turkey & - \\
\hline 53 & 52S: view of the black sea & Turkey & vignette, 5th frontispiece Flora Graeca \\
\hline 54 & 53S: Istanbul & Turkey & $\begin{array}{l}\text { vignette, 4th frontispiece Flora Graeca; Harris, } \\
2007\end{array}$ \\
\hline
\end{tabular}




\begin{tabular}{|c|c|c|c|}
\hline Number & Scene and legend & Country & Reference \\
\hline 55 & 54S: Istanbul & Turkey & - \\
\hline 56 & $56^{*}$ : towers of Oblivion & Turkey & - \\
\hline 57 & 57S: tower of Oblivion & Turkey & - \\
\hline 58 & 58S: Besiktas Shore Palace & Turkey & - \\
\hline 59 & 59S: a castle on Black Sea coast & Turkey & - \\
\hline 60 & 60S: a village near Istanbul & Turkey & - \\
\hline 61 & 61S: an ancient aqueduct & Turkey & - \\
\hline 62 & 62S: the Sea of Marmara & Turkey & - \\
\hline 63 & 63S: coasts of Asia & Turkey & - \\
\hline 64 & 64: coasts of Asia & Turkey & Harris, 2007 \\
\hline 65 & $65 \mathrm{~S}$ : a village on the island Karki & Turkey & - \\
\hline 66 & 66: Princes Islands & Turkey & - \\
\hline 67 & 67S: one of the Princes Islands & Turkey & - \\
\hline 68 & 68: Prinkiponhsa & Turkey & - \\
\hline 69 & 69S: Prinkiponhsa & Turkey & - \\
\hline 70 & 70S: old castles & Turkey & - \\
\hline 71 & 71s: old castle & Turkey & - \\
\hline 72 & 72S: Dardanelles & Turkey & Harris, 2007 \\
\hline 73 & 73S: Dardanelles & Turkey & - \\
\hline 74 & 74S: Dardanelles & Turkey & - \\
\hline 75 & 75: Tenedos & Turkey & - \\
\hline 76 & 76: Karapaktar & Turkey & - \\
\hline 77 & 77: Karapaktar & Turkey & - \\
\hline 78 & 78: a coast of the gulf Macri & Turkey & - \\
\hline 79 & 79S: port of Rhodes & Greece & - \\
\hline 80 & 80: Monte Croce, Mt Staveros & Cyprus & - \\
\hline 81 & 81: Holy Cross monastery & Cyprus & - \\
\hline 82 & 82: the village Ipsora & Cyprus & Harris, 2007 \\
\hline 83 & 83: port Finica & Turkey & - \\
\hline 84 & 84: coast of Turkey & Turkey & - \\
\hline 85 & 85S: a village near Porto Finica & Turkey & - \\
\hline 86 & 86: Leros island & Greece & - \\
\hline 87 & 87S: Leros island & Greece & - \\
\hline 88 & 88: Patmos island & Greece & - \\
\hline 89 & 89: Patmos houses people & Greece & - \\
\hline 90 & 90: monastery of Apocalypse & Greece & Lack and Mabberley, 1999 \\
\hline 91 & 92*: Skinousa island & Greece & - \\
\hline 92 & 93: Aegean islands & Greece & - \\
\hline 93 & 94: Kimolos island & Greece & - \\
\hline 94 & 98*: Phaleron bay and Attica & Greece & - \\
\hline 95 & 99: Phaleron bay & Greece & - \\
\hline 96 & 100: Athens panoramic view & Greece & $\begin{array}{l}\text { vignette, 6th frontispiece Flora Graeca; } \\
\text { Stearn, 1976; Rhizopoulou, 2004; Harris, } \\
2007\end{array}$ \\
\hline 79 & 101S: Theseum temple & Greece & - \\
\hline 98 & 102S: Theseum temple & Greece & - \\
\hline 99 & 103S: Theseum temple & Greece & - \\
\hline 100 & 104S: Philopappou monument & Greece & - \\
\hline 101 & 105: theatre Herodes Atticus & Greece & - \\
\hline 102 & 106: temple of Zeus Olympios & Greece & - \\
\hline 103 & 107S: Adrian gate at Athens & Greece & Lack and Mabberley, 1999 \\
\hline 104 & 108: a fountain near Livadia & Greece & - \\
\hline 105 & 109: Trophonius' grotto site & Greece & - \\
\hline 106 & 110: a view of Livadia & Greece & - \\
\hline 107 & 111S: Trophonius grotto & Greece & - \\
\hline 108 & 112S: Parnassus & Greece & $\begin{array}{l}\text { vignette, 1st frontispiece Flora Graeca; } \\
\text { Krimbas, 2004; Harris, } 2007\end{array}$ \\
\hline 109 & $115^{*}$ : the temple at Sounio & Greece & - \\
\hline 110 & 119*: the temple at Sounio & Greece & - \\
\hline
\end{tabular}




\begin{tabular}{llll}
\hline Number & Scene and legend & Country & Reference \\
\hline 111 & 120: Negroponte bridge & Greece & - \\
112 & 121: Negroponte bridge castle & Greece & - \\
113 & 122: Negroponte bridge castle & Greece & - \\
114 & 123S: Negroponte castles & Greece & - \\
115 & 124: Negroponte: customs & Greece & - \\
116 & 125S: Iviri monastery in Athos & Greece & - \\
117 & 126S: the summit of Mt Athos & Greece & Harris, 2007 \\
118 & 127S: a convent of Mt Athos & Greece & vignette, 2nd frontispiece Flora Graeca; Lack \\
& & Greece & and Mabberley, 1999 \\
119 & 128S: west coast of Mt Athos & Greece & - \\
120 & 129S: Thessalonica & Greece & - \\
121 & 130: gulf of Thessalonica & Greece & - \\
122 & 131: a village near Thessalonica & Greece & - \\
123 & 132S: ruins of Eleusis & Greece & - \\
124 & 133S: the port of Megara & Greece & - \\
125 & 134: Isthmus of Corinth & Greece & - \\
126 & 135S: ancient temple in Corinth & Greece & vignette, 7th frontispiece Flora Graeca; Lack \\
127 & 136S: Corinth panoramic & & and Mabberley, 1999 \\
& & Greece & - \\
128 & 137: Isthmus of Corinth & Greece & Lack and Mabberley, 1999 \\
129 & 139*: Patras, panoramic view & U.K. & - \\
130 & 140: the rock of Gibraltar & U.K. & - \\
131 & 141: the harbour of Gibraltar & &
\end{tabular}

\section{REFERENCES}

Antrop M., (2005), Why landscapes of the past are important for the future?, Landscape and Urban Planning, 70, 21-34.

Baltas E.A., Dervos N.A. and Mimikoy M.A., (2010), Impact of changing rainfall conditions on surface and groundwater resources in an experimental watershed in Greece, Global NEST J., 12, 119-125.

Başkale E. and Kaya U., (2009), Richness and distribution of amphibian species in relation to ecological variables in Western Aegean region of Turkey, Ekoloji, 18, 25-31.

Braudel F., Corelli F. and Aymarad M., (1985), La Méditerranée, l'espace et l'histoire, Flammarion, Paris.

Bruce M.R., (1970), John Sibthorp, Taxon, 19, 353-360.

Cosgrove D., (2006), Modernity, community and the landscape idea, Journal of Material Culture, 11, 4966.

Daskalothanassis N., (2004), Nature as landscape, In: Landscapes, Simmel, G., Ritter J. and Gombrich E.H. (Eds), Potamos, Athens.

Digital Flora Graeca, [www.bodley.ox.ac.uk/users/millsr/isbes/FG/MedScenes].

Georghiou K. and Delipetrou P., (2010), Patterns and traits of the endemic plants of Greece, Botanical Journal of the Linnean Society, 162, 130-422.

Harris S., (2007), The Magnificent Flora Graeca, The Bodleian Library, Oxford.

Jones-Walters L. and Čivić K., (2010), Wilderness and biodiversity, Journal for Nature Conservation, 18, 338-339.

Harvey D.C., (2001), Heritage pasts and heritage presents: temporality, meaning and the scope of heritage studies, International Journal of Heritage Studies 7, 319-338.

Kay R.F., Madden R.H., Van Schaik C. and Higdon D., (1997), Primate species richness is determined by plant productivity: implications for conservation, Proceedings of the National Academy of Sciences of USA, 94, 13023-13027.

Kent M., (2009), Biogeography and landscape ecology: the way forward - gradients and graph theory, Progress in Physical Geography, 33, 424-436.

Krimbas C.B., (2004), H Walter Lack with David J Mabberley, the Flora Graeca story - Sibthorp, Bauer and Hawkins in the Levant, Historical Review, 1, 275-284.

Lack W.H., (1997), The Sibthorpian herbarium at Oxford, Taxon, 46, 253-263.

Lack, W.H. and Mabberley D.J., (1999), The Flora Graeca story, Sibthorp, Bauer and Hawkins in the Levant, Oxford University Press, Oxford.

Lardos A., (2006), The botanical materia medica of the latrosophikon: a collection of prescriptions from a monastery in Cyprus, Journal of Ethnopharmacology, 104, 387-406. 
Lhotskt J., (1843), Biographical Sketch of Ferdinand Bauer, London Journal of Botany, 2, 106-113.

Lymberakis P. and Poulakakis N., (2010), Three continents claiming an Archipelago: the evolution of Aegean's herpetofauna, Diversity 2, 233-255.

Mayr E., (1982), The growth of biological thought: diversity, evolution and inheritance, The Belknap Press of Harvard University Press, Cambridge Mass. and London.

McAllister R.R.J., Izquierdo L.R., Janssen M.A. and Stafford Smith D.M., (2009), Research impact within the international arid literature: an Australian perspective based on network theory. Journal of Arid Environments 73, 862-971.

Mills, R. and Townsend, A.-M., (1991), The Sherard collection: University of Oxford. New Library World, 4-5.

Myers N., Mittermeier R.A., Mittermeier C.G., da Fonseca G.A.B. and Kent J., (2000), Biodiversity hotspots for conservation priorities, Nature, 403, 853-858.

Naveh Z., (1998), Form biodiversity to ecodiversity - holistic conservation of the biological and cultural diversity of Mediterranean landscapes, In: Rundel, P., Montenegro, G. and Jaksic, F.M. (Eds), Landscape disturbance and biodiversity in Mediterranean-type ecosystems, Springer, Berlin.

Nickelsen K., (2006), Draughtsmen, botanists and nature: constructing eighteenth-century botanical illustrations, Studies in History and Philosophy of Biological and Biomedical Sciences, 37, 1-25.

Pafilis P., (2010), A brief history of Greek herpetology, Bonn Zoological Bulletin 57, 329-345.

Rhizopoulou S., (2004), Symbolic plant(s) of Olympic Games, Journal of Experimental Botany, 55, 16011606.

Rhizopoulou S., (2007), Flora Graeca, Neusis, 16, 34-44.

Rhizopoulou S., (2008), Radical Research on the Wandering of Dioscorides in Manuscripts, Codices and Books. Diavlos, Athens.

Rhizopoulou S. and Harris S., (2009), Magnificent Flora Graeca, In: Proceedings of the 11th Symposium of the Hellenic Botanical Society, Athens.

Sclater P.L., (1904), On the birds of Sibthop's Fauna Graeca, Ibis, 8, 222-227.

Sibthorp J. and Smith J.E., (1806-1840), Flora Graeca: Sive Plantarum Rariorum Historia, quas in Provinciis aut Insulis Graeciae, Richard Taylor, London.

Smocovitis V.B., (2003), Fielding Biology, Science, 299, 1665-1666.

Stearn W.T., (1976), From Theophrastus and Dioscorides to Sibthorp and Smith: the background and origin of the Flora Graeca, Biological Journal of the Linnean Society, 8, 285-298.

Strid A. and Strid B., (2009), Sibthorp \& Smith Flora Graeca annotated re-issue (vol. 1, 2), A.R.G. Gantner Verlag K.G., Liechtenstein.

Terkenli T.S., (2001), Towards a theory of the landscape: the Aegean landscape as a cultural image. Landscape and Urban Planning, 57, 3-4.

Tregaskis H., (1979), Beyond the Grand Tour, the Levant lunatics, Ascent Books, London.

Türe C. and Börük H., (2010), Distribution patterns of threatened endemic plants in Turkey: A quantitative approach for conservation, Journal for Nature Conservation, 18, 296-303.

Vogiatzakis I.N., Mannion A.M. and Griffiths G.H., (2006), Mediterranean ecosystems: problems and tools for conservation, Progress in Physical Geography, 30, 175-200.

Wise R., (1989), A naturalist's paradise, The New Scientist, 123, 68. 